Eur. J. Clin. Chem. Clin. Biochem.

Vol. 32, 1994, pp. 915-921

(c) 1994 Walter de Gruyter \& Co. Berlin - New York

\title{
Acute Intermittent Porphyria: Diagnostic Conundrums
}

\author{
By W. S. Wassif ${ }^{1}$, A. C. Deacon' ${ }^{2}$ Ylva Floderus ${ }^{3}$, S. Thunell ${ }^{3}$ and T. J. Peters ${ }^{1}$ \\ 1 Department of Clinical Biochemistry, King's College School of Medicine and Dentistry, London, UK \\ 2 Department of Clinical Chemistry, Northwick Park Hospital, Harrow, Middlesex, UK \\ 3 National Porphyrias Service, St Göran's Hospital, Stockholm, Sweden
}

(Received June 6/September 20, 1994)

Summary: Acute intermittent porphyria is a genetic disorder of haem biosynthesis caused by defects in the gene encoding hydroxymethylbilane synthase on the long arm of chromosome 11. Every effort should be made to identify gene carriers amongst the relatives of patients known to have acute intermittent porphyria as they are at risk of developing potentially fatal neurogenic attacks if exposed to precipitating factors. Erythrocyte hydroxymethylbilane synthase activity was determined in 46 members of two large well characterised families by assaying enzyme activity by both high performance liquid chromatography (HPLC) and fluorimetric assays. Additionally, hydroxymethylbilane synthase immunoreactivity was determined by a sandwich-type ELISA. Statistically significant correlations were observed between erythrocyte hydroxymethylbilane synthase activity assayed by HPLC and by the fluorimetric assay, and enzyme protein concentration ( $r=0.85, \mathrm{p}<0.001$ and $\mathrm{r}=0.80, \mathrm{p}<0.001$, respectively). The assay of hydroxymethylbilane synthase immunoreactive concentration in erythrocytes was useful in excluding acute intermittent porphyria in one patient in whom unequivocal assignment of porphyric status was not possible by assaying enzyme activity alone. Erythrocyte hydroxymethylbilane synthase activity assayed by HPLC and fluorimetry showed approximately equal diagnostic performances, both giving rise to a dichotomic distribution of values, with overlap zones of $6 \%(1 / 16)$ and $22 \%(2 / 9)$, respectively, at the "cut off" applied.

\section{Introduction}

Acute intermittent porphyria is an autosomal dominant disorder of haem biosynthesis in which over-production of haem precurrsors is associated with characteristic clinical features and a potentially fatal neuropsychiatric syndrome $(1,2)$. Acute intermittent porphyria is caused by defects in the gene encoding hydroxymethylbilane synthase (EC 4.3.1.8), ${ }^{1}$ ) also known as porphobilinogen deaminase (3). Hydroxymethylbilane synthase is a cytosolic enzyme and has reduced activity in abnormal gene carriers $(2,4)$.

It is important to investigate asymptomatic individuals for latent or subclinical porphyria and every effort

\footnotetext{
l) Enzyme:

Hydroxymethylbilane synthase also known as porphobilinogen deaminase (EC 4.3.1.8)
}

should be made to identify gene carriers amongst the relatives of patients known to have acute intermittent porphyria (5). Normal haem precursors usually occur. in asymptomatic gene carriers. Furthermore, normal porphyrin excretion may occur in known patients with acute intermittent porphyria during the remission periods (6). Low erythrocyte hydroxymethylbilane synthase activity is specifically diagnostic of acute intermittent porphyria $(2,7)$ and remains the most effective method for detecting gene carriers $(8,9)$. Nevertheless, unequivocal assignment confirming or refuting the diagnosis of acute intermittent porphyria cannot be achieved among some relatives of a known patient with acute intermittent porphyria due to the overlap in enzyme activities between affected patients and normal subjects $(8-10)$.

Molecular heterogeneity in acute intermittent porphyria (11) and the large number of point mutations (12-14) 
detected so far, make genetic studies in affected families an impractical option at the present time. None of the mutations so far identified has been found to occur more frequently than any of the others, and many of these mutations appear to be unique to one family. Additionally, all polymorphic sites are clustered within a small fragment $\left(1.5 \times 10^{3}\right.$ bases in the first intron) of the hydroxymethylbilane synthase gene and thus limiting the usefulness of restriction fragment length polymorphisms in identifying and differentiating the mutant allele from the normal one (15). However, restriction fragment length polymorphisms have been successfully used for haplotype analysis and heterozygote carrier detection in specific families with acute intermittent porphyria (16, 17).

In this study, the level of hydroxymethylbilane synthase gene expression in erythrocytes was determined in two large well characterised families by assaying hydroxymethylbilane synthase activity by both high performance liquid chromàtography (HPLC) of the reaction products (18), and by a fluorimetric assay (19). In addition, immunoreactive enzyme was assayed by ELISA (20). The aim of this study was to assess the performance of assays measuring hydroxymethylbilane synthase activity, to document the degree of overlap in enzyme activities between gene carriers and normal subjects using different methods, and secondly, to investigate whether determination of hydroxymethylbilane synthase immunoreactivity and specific enzyme activities have a better diagnostic performance in individuals with equivocal hydroxymethylbilane synthase activities.

\section{Patients and Methods}

Patient details

We studied 46 members from two large well characterised families: 33 members aged 2 to 70 years (mean $\pm S E M, 34.5 \pm 3.4$ years) (19 females and 14 males) were investigated from family 1 (fig. 1 ), and 13 individuals aged 5 to 50 years (mean \pm SEM, 28.2 \pm 4.4 years) ( 7 females and 6 males) from family 2 (fig. 2) were studied.

\section{Urinary and faecal porphyrin quantification}

Urinary and faecal porphyrins were identified and quantified by high performance liquid chromatography (HPLC) according to the method of Lim \& Peters (21). If acute porphyria was suspected, urinary 5-aminolaevulinic acid and porphobilinogen excretion were quantified after prior purification by anion-exchange chromatography (22).

\section{Erythrocyte hydroxymethylbilane synthase activity}

Hydroxymethylbilane synthase activity was assayed by the HPLC method of Wright \& Lim (18) using fresh heparinised erythrocytes. The enzyme activity was expressed as uroporphyrin, $\mu \mathrm{mol} / \mathrm{h} \cdot 1$ erythrocytes. The between-run coefficient of variation was $8 \%$ at a level of 25 uroporphyrin, $\mu \mathrm{mol} / \mathrm{h} \cdot \mathrm{l}$ erythrocytes. Hydroxymethylbilane synthase activity was also determined by the fluorimetric assay of Magnussen et al. (19) with the assay of haemoglobin in the haemolysate (23). Enzyme activity was related to haemoglobin concentration and expressed as pkat/g $\mathrm{Hb}$. The between-run coefficients of variation of the fluorimetric assay were $2.1 \%$ and $5.4 \%$ for healthy and porphyric subjects, respectively. The lower reference limit applied was 90 pkat/g Hb, representing a diagnostic sensitivity of $97 \%$ and a specificity of $85 \%$. Non-gene carriers do not exhibit erythrocyte hydroxymethylbilane synthase activities below $70 \mathrm{pkat} / \mathrm{g} \mathrm{Hb}$, a value representing a "cut off" limit giving a sensitivity of $100 \%$, but a low specificity of $47 \%$ (24).

Erythrocyte hydroxymethylbilane synthase concentration

Hydroxymethylbilane synthase concentration was assayed by a sandwich-type ELISA with monospecific polyclonal antiserum (IgG) raised against hydroxymethylbilane synthase, as previously described (20). Haemoglobin concentration (absorbance read at $410 \mathrm{~nm}$ ) of the samples was determined and hydroxymethylbilane synthase concentration was expressed relative to haemoglobin concentration as $\mu \mathrm{g} / \mathrm{g} \mathrm{Hb}$. Erythrocytes hydroxymethylbilane synthase specific activity was determined by dividing enzyme activity with enzyme protein concentration, and expressed as nkat/g enzyme protein (20). A lower reference limit of $110 \mu \mathrm{g} / \mathrm{g} \mathrm{Hb}$ was used. This "cut off" value gives a diagnostic sensitivity of $85 \%$ and specificity of $85 \%$ (24).

\section{Further blood analyses}

All patients had assays for full blood count, white cell differential and subset assays. Biochemical profile including renal and liver function and toxicity tests was carried-out on the DAX-48 multichannel analyser (Bayer Diagnostics, Basingstoke, UK) by standard methods.

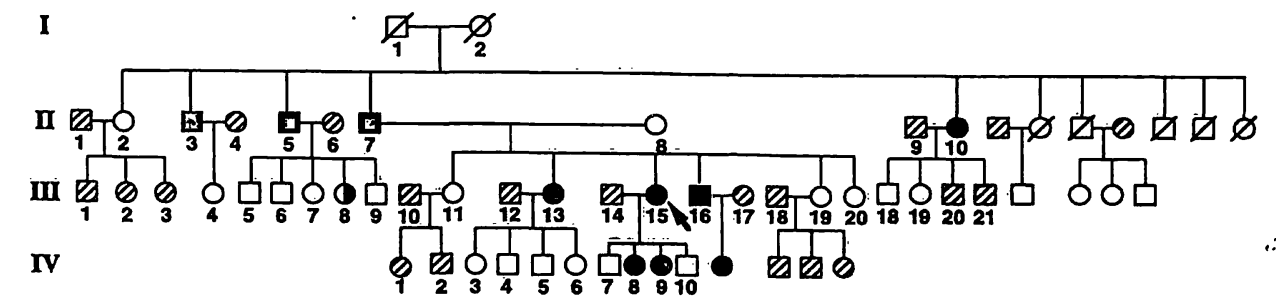

Fig. 1 Pedigree of family 1 showing autosomal dominant inheritance of acute intermittent porphyria. Affected individuals are represented by black symbols (*0), unaffected individuals are depicted as open symbols $(\square 0)$, while members who were not inves- tigated are represented by hatched symbols ( $\theta)$. Patient III:8, in whom definitive porphyric status was not possible, is represented by half-filled symbol (0). \ indicates propositus. 


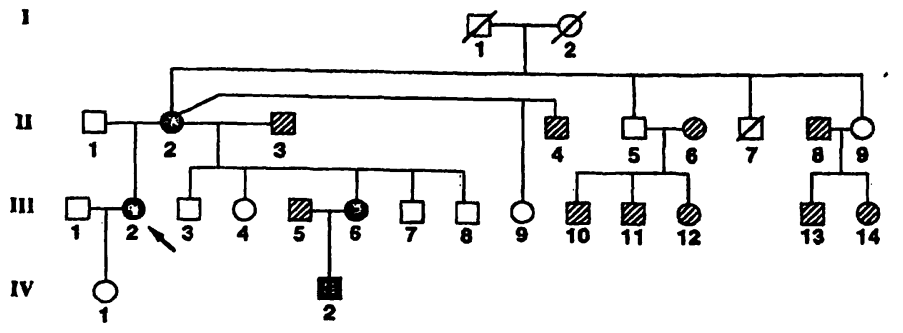

Fig. 2 Pedigree of family 2 showing autosomal dominant inheritance of acute intermittent porphyria. Affected individuals are represented by black symbols ( $\boldsymbol{0} \bullet$ ), unaffected individuals are depicted as open symbols ( $\square$ O), while members who were not investigated are represented by hatched symbols $(\square)$ ). \indicates propositus.

\section{Results}

In the two families the propositus (patient III:15, fig. 1; patient III:2, fig. 2) presented at the age of 34 and 27 years, respectively, with a history of dieting prior to hospital admission. Both index patients were admitted to hospital with severe abdominal pain, hypertension, vomiting and constipation and had elevated urinary excretion of 5-aminolaevulinic acid, porphobilinogen, raised urinary porphyrin and normal faecal porphyrin (tab. 1). The decreased red cell hydroxymethylbilane synthase activity in both patients (assayed by HPLC, tab. 1) was consistent with the diagnosis of acute intermittent porphyria.

Tab. 1 Urinary 5-aminolaevulinic acid and porphobilinogen excretion, urinary and faeçal porphyrins pattern and erythrocyte hydroxymethylbilane synthase activity in the two index patients.
Assay of erythrocyte hydroxymethylbilane synthase activity (by the HPLC technique) in 33 members of family 1 (fig. 1) identified 11 (33\%) individuals as gene carriers. Twenty one family members did not inherit the gene defect. In one individual (patient III:8, fig. 1) unequivocal assignment confirming or refuting the diagnosis of acute intermittent porphyria was not possible by assay of hydroxymethylbilane synthase activity alone due to the overlap in enzyme activities between affected patients and normal subjects $(8-10)$. Of 13 members of family 2 (fig. 2) 4 (31\%) patients were identified as gene carriers. There was no overlap in enzyme activity in family 2 and unequivocal assignment excluding acute intermittent porphyria was possible in the other 9 family members. All gene carriers in both families, with the exception of the two index patients, had urinary and faecal porphyrins and urinary 5-aminolaevulinic acid and porphobilinogen within the reference ranges. Of 15 gene carriers, only $2(13 \%)$ patients (patient III:15, fig. 1; patient III:2, fig. 2) developed attacks of acute intermittent porphyria.

To characterize further the defect in acute intermittent porphyria, and establish a definitive diagnosis in the subjects with equivocal hydroxymethylbilane synthase activity, 22 members (11 from each family) were subjected to further investigations including the measurement of hydroxymethylbilane synthase immunoreactive

Hydroxymethylbilane synthase activity was assayed by the method of Wright \& Lim (18).

$\begin{array}{lll}\begin{array}{l}\text { Patient III:15 } \\ \text { (fig. 1) }\end{array} & \begin{array}{l}\text { Patient III:2 } \\ \text { (fig. 2) }\end{array} & \text { Reference ranges }\end{array}$

\section{Urine}

5-Aminolaevulinic acid

Porphobilinogen

Uroporphyrin I

Uroporphyrin III

Total ưroporphyrin $(\mathrm{I}+\mathrm{III})$

Heptacarboxylate porphyrin

Hexacarboxylate porphyrin

Pentacarboxylate porphyrin

Coproporphyrin I

Coproporphyrin III!

Total coproporphyrin $(I+I I)$

Faeces

Coproporphyrin I

Coproporphyrin III

Total coproporphyrin (I + III)

Protoporphyrin IX

Blood

Erythrocyte hydroxymethylbilane synthase activity

356
261
2360
2240
4600
ND
ND
ND
150
131
281

281

21

30

32

13

$$
\begin{aligned}
& <34 \mu \mathrm{mol} / 1 \\
& <8 \mu \mathrm{mol} / / \\
& \\
& \\
& <24 \mathrm{nmol} / 1 \\
& <4 \mathrm{nmol} / / \\
& <3 \mathrm{nmol} / 1 \\
& <5 \mathrm{nmol} /
\end{aligned}
$$

$<115 \mathrm{nmol} / \mathrm{h}$ 
concentration. Additionally, enzyme activity was measured by the independent fluorimetric assay described by Magnussen et al. (19) and specific enzyme activity was determined. Of the 22 subjects 8 had been classified as gene carriers by the HPLC method, 13 were normal and not at risk of acute intermittent porphyria, and in one member porphyric status was questionable as erythrocyte hydroxymethylbilane synthase activity was equivocal as shown in table 2 . Seven out of eight individuals diagnosed as gene carriers by the HPLC method were identified as such by the fluorimetric assay. One individual given the diagnosis of acute intermittent porphyria by the HPLC method, exhibited a value just above the reference value applied when erythrocyte hydroxymethylbilane synthase activity was assayed by the fluorimetric assay, as did the individual exhibiting equivocal result in the HPLC assay. Thus both assays show similar diagnostic efficiency and give rise to a relatively clear-cut dichotomic distribution of gene carriers and non-carriers (fig. 3).
It is clear from table 2 that all gene carriers had hydroxymethylbilane synthase concentrations below $110 \mu \mathrm{g} / \mathrm{g}$ $\mathrm{Hb}$. The measurement of hydroxymethylbilane synthase concentration in erythrocytes was useful in excluding acute intermittent porphyria in patient III:8 (family 1 , fig. 1, tab. 2) who had equivocal enzyme activity using the HPLC assay but had hydroxymethylbilane synthase concentration of $125 \mu \mathrm{g} / \mathrm{g} \mathrm{Hb}$. However, there was one overlap in hydroxymethylbilane synthase concentration in a normal subject (subject III:8, family 2, fig. 2, tab. 2) who did not inherit the gene defect but had hydroxymethylbilane synthase concentration of $90 \mu \mathrm{g} / \mathrm{g} \mathrm{Hb}$. As shown in table 2, hydroxymethylbilane synthase specific actiivty was not helpful in identifying patients at risk of acute intermittent porphyria and there was no clear separation in enzyme specific activity between gene carriers and normal subjects. Indeed, there was no correlation between hydroxymethylbilane synthase specific activity and both enzyme activity and enzyme concentration $(r=0.42, p=0.06$ and $r=0.14, p=0.52$, respec-

Tab. 2 Erythrocyte hydroxymethylbilane synthase activity, concentration and specific activity in the two families with acute intermittent porphyria.

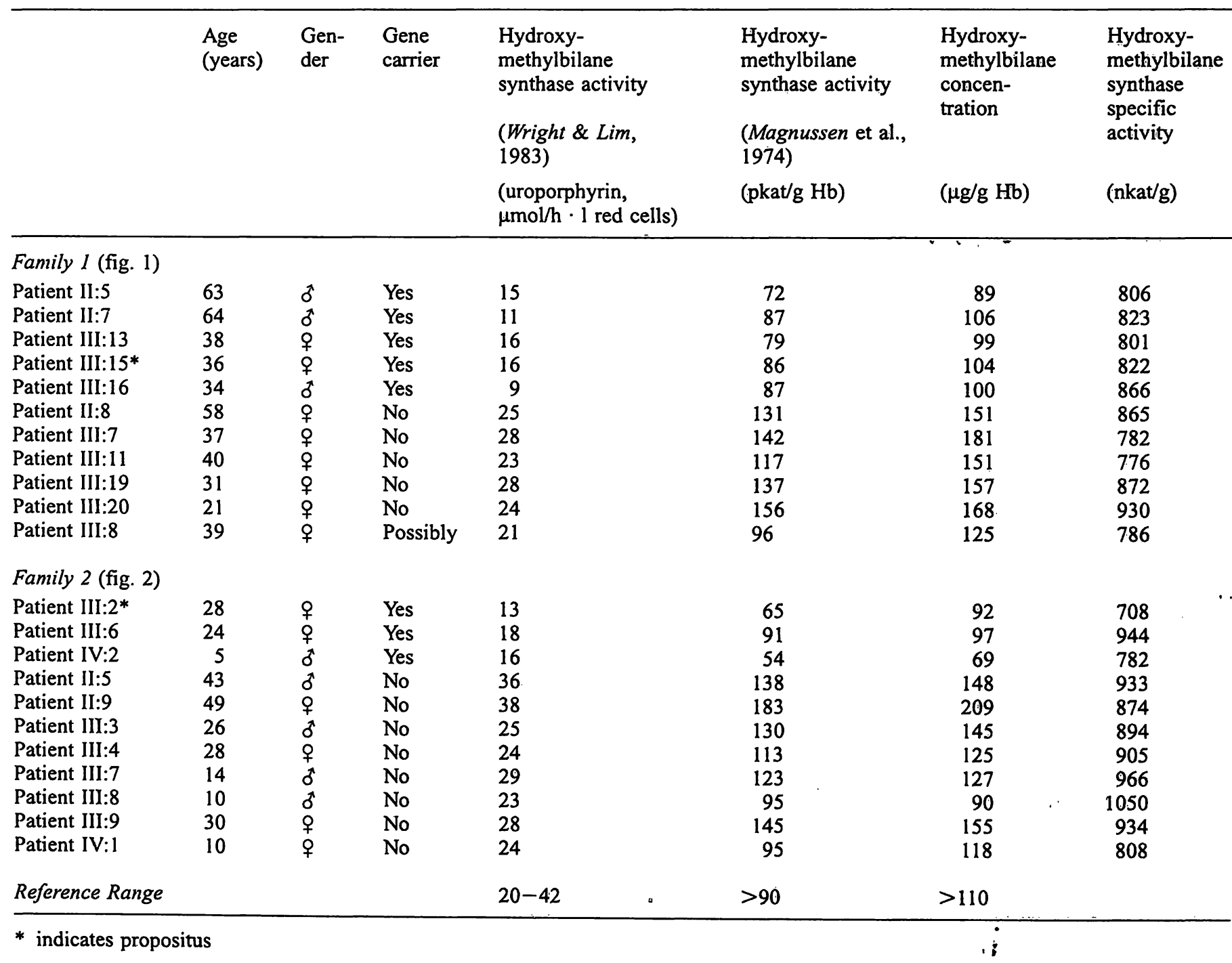



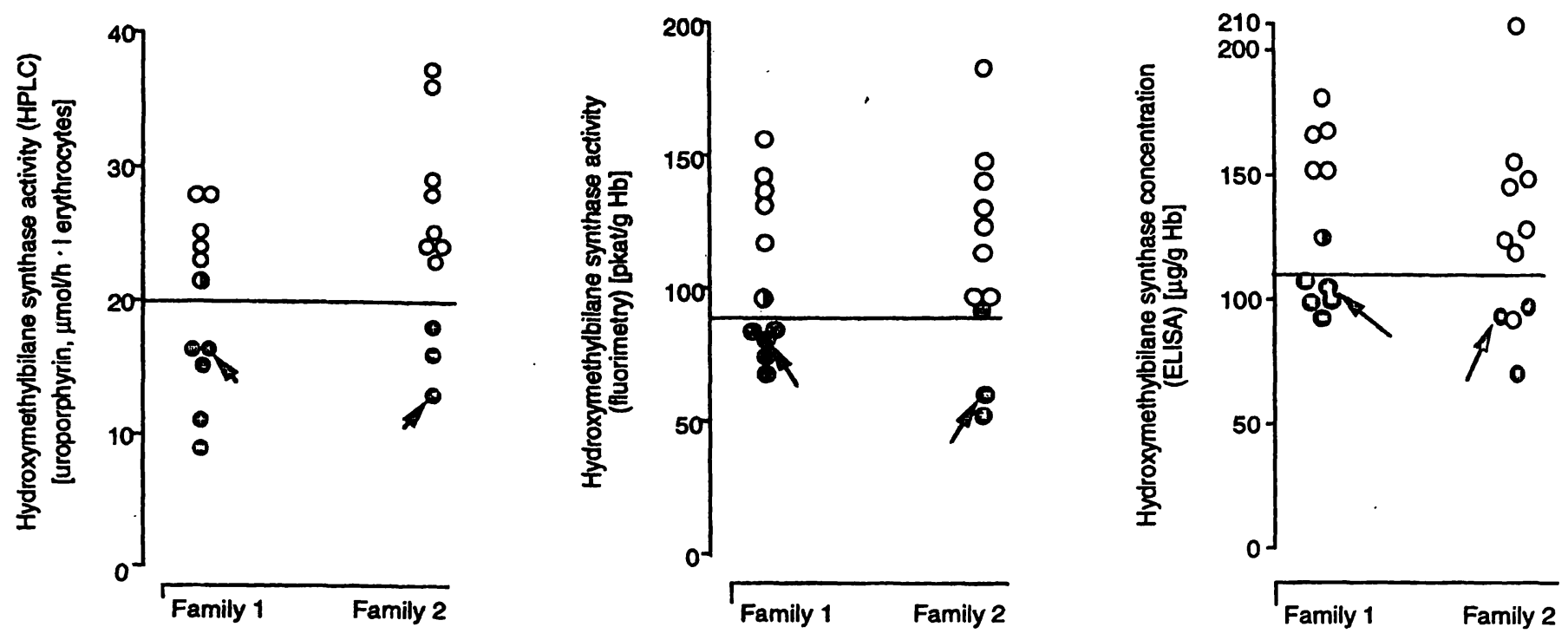

Fig. 3 Erythrocyte hydroxymethylbilane synthase activity and concentration in two families with acute intermittent porphyria. Hydroxymethylbilane synthase activities were determined by the HPLC method of Wright \& $\mathrm{Lim}^{18}$ and the fluorimetric method of
Magnussen et al. ${ }^{19}$. Carrier status was arbitrarily assigned using the HPLC assay data. The lower limits of the reference ranges of various assays are represented with solid lines. Gene carriers $(\boldsymbol{0})$, non carriers $(0)$ and equivocal status $(0) . /$ indicates propositus. tively). In contrast, statistically significant correlations were observed between erythrocyte hydroxymethylbilane synthase activity assayed by the method of Wright \& Lim and enzyme activity determined by the method of Magnussen et al., and enzyme concentration $(\mathrm{r}=0.85, \mathrm{p}<0.001$ and $\mathrm{r}=0.80, \mathrm{p}<0.001$ respectively, $\mathrm{n}=22$ ). A highly significant correlation was also observed between erythrocyte hydroxymethylbilane synthase activity assayed according to the method of Magnussen et al. and hydroxymethylbilane synthase concentration $(r=0.96, p<0.001, n=22)$.

All members investigated from both families had normal biochemical profiles and haematological indices except 2 gene carriers from family 2 (patients III: 6 and IV:2, fig. 2) who had iron deficiency anaemia and a repeat hydroxymethylbilane synthase activity was performed after iron replacement therapy.

\section{Discussion}

The elevated urinary excretion of 5-aminolaevulinic acid and porphobilinogen in both index patients is consistent with the diagnosis of one of the acute porphyrias (i. e., acute intermittent porphyria, variegate porphyria and hereditary coproporphyria). The raised urinary porphyrin content (tab. 1) has probably arisen by non-enzymic polymerization of porphobilinogen in the urine to form a mixture of uroporphyrin isomers. The normal faecal porphyrin excretion in both patients indicates that variegate porphyria and hereditary coproporphyria are highly unlikely, whereas the decreased red cell hydroxymethylbi- lane synthase activity (tab. 1) is consistent with acute intermittent porphyria.

The dominant mode of inheritance, the occurrence of asymptomatic gene carriers and the risk of developing potentially fatal attacks if exposed to a wide range of common precipitating factors, make it essential to exclude or confirm the diagnosis of acute intermittent porphyria in all relatives whenever the diagnosis has been made in one member of the family $(2,7)$. Patients with acute intermittent porphyria are at risk of developing potentially fatal neurogenic attacks if exposed to exogenous precipitating factors including a wide range of commonly prescribed drugs (25), alcohol, fasting, stress, hormones $(2,26)$ and, interestingly, if they continue to smoke (27). In our study, the index patients in both families had acute attacks of porphyria following low calorie diet for weight reduction.

In our hands the HPLC and fluorimetric assays for erythrocyte hydroxymethylbilane synthase activity showed about the same diagnostic efficiency at the "cut off" levels applied, 8 and 7 individuals, respectively, diagnosed as gene carriers. However, it is clear that, whichever assay is used, there was a small overlap between enzyme activities in normal subjects and gene carriers in our study as in previous studies $(8-10)$. It is well established that a definitive assignment of porphyric status cannot always be made in all relatives, even when porphobilinogen excretion, 5-aminolaevulinic acid synthase activity (28) and gene dosage effect (9) are taken into account. Lamon et al. demonstrated that pedigree analysis with respect to the frequency distribution 
of hydroxymethylbilane synthase enzyme activities in family members was successful in establishing porphyric status in $50 \%$ of those subjects with equivocal enzyme activity (9). It is noteworthy that the existence of a variant of acute intermittent porphyria has been reported where enzyme defect is not expressed in erythrocytes (29), in such families the measurement of erythrocyte hydroxymethylbilane synthase activity is unhelpful.

In this study, the measurement of erythrocyte hydroxymethylbilane synthase immunoreactive concentration was useful in excluding the diagnosis of acute intermittent porphyria in one member who had equivocal hydroxymethylbilane synthase activity. The estimation of enzyme specific activity was not useful in identifying gene carriers with no clear separation between normal subjects and gene carriers. This is hardly surprising since there is a good correlation between hydroxymethylbilane synthase activity and enzyme protein concentration. This indicates that in these two families there is either no gene product or that the protein produced is neither catalytically active nor recognised by the anti-serum used in the ELISA, i.e., we are dealing with a form of acute intermittent porphyria in which no cross reacting immunoreactive material (CRIM) is produced (CRIM negative). Since hydroxymethylbilane synthase activity decreases as red cells age any shift in their age distribution will be reflected in the enzyme activity (5), a repeat of hydroxymethylbilane synthase activity was essential in the two suspected gene carriers after the correction of the haematological abnormalities.

\section{Acknowledgements}

We are grateful to Dr Hughes, Department of Medicine, Pembury Hospital and to Dr B. Hoffbrand, Department of Medicine, The Whittington Hospital for referring the index patients. We wish to thank Dr Ruth Ayling and Dr Roy Sherwood, Department of Clinical Biochemistry, King's College Hospital for their critical comments on the manuscript, Dr Richard Fink and Dr Nick Walcot, West Middlesex University Hospital for their advice and Dr $E$. Baylis and Mrs A. Hayward, Department of Clinical Chemistry, Kent and Sussex Hospital for their assistance in sample collection.

\section{References}

1. Waldenstrom, J. (1937) Studien über Porphyrie. Acta Med. Scand. Suppl. 82, 1.

2. Kappas, A., Sassa, S., Galbraith, R. A. \& Nordman, Y. (1989) The porphyria. In: The Metabolic Basis of Inherited Diseases, 6th edn. (Scriver, C. R., Beaudet, A. L., Sly, W. S. \& Valle, D., eds.) pp. 1305-1366, McGraw-Hill Book Company, New York.

3. Meisler, M., Wanner, L., Eddy, R. E. \& Shows, T. B. (1980) The UPS locus encoding uroporphyrinogen I synthase is located in human chromosome 11. Biochem. Biophys. Res. Commun. 95, 170-176.

4. Poulos, V., Blake, C., McManus, J. \& Rossi, E. (1991) Haem biosynthetic enzymes. Clin. Biochem. Revs. 12, 31-33.

5. Elder, G. H., Smith, S. G. \& Jane Smyth, S. (1990) Laboratory investigation of the porphyrias. Ann. Clin. Biochem. 27, 395-412.

6. Doss, V. M. \& Tiepermann, R. V. (1978) UroporphyrinogenSynthase in Erythrocyten bei akuter intermittierender Porphyrie: Neue pathobiochemische Aspekte. J. Clin. Chem. Clin. Biochem. 16, 111-118.

7. Kappas, A., Sassa, S. \& Anderson, K. (1983) The porphyria. In: The Metabolic Basis of Inherited Diseases, 5th edn. (Stanbury, J. B., Wyngaarden, J. B., Fredrickson, D. S., Goldstein, J. L. \& Brown, M. S., eds.) pp. 1301-1384, McGraw-Hill Book Company, New York.

8. Pierach, C. A., Weimer, M. K., Cardinal, R. A., Bossenmaier, I. C. \& Bloomer, J. R. (1987) Red blood cell porphobilinogen deaminase in the evaluation of acute intermittent porphyria. J. Am. Med. Ass. 257, 60-61.

9. Lamon, J. M., Frykholm, B. G. \& Tschudy, D. P. (1979) Family evaluations in acute intermittent porphyria using red cell uroporphyrinogen I synthase. J. Med. Genet. 16, 134-139.

10. Bonaiti-Pellie, C., Phung, L. \& Nordmann, Y. (1984) Recurrence risk estimation of acute intermittent porphyria based on analysis of porphobilinogen deaminase activity: A Bayesian approach. Am. J. Med. Genet. 19, 755-762.

11. Desnick, R. J., Ostasiewicz, L. T., Tishler, P. A. \& Mustajoki, P. (1985) Acute intermittent porphyria: Characterization of a novel mutation in the structural gene for porphobilinogen deaminase. J. Clin. Invest. 76, 865-874.

12. Grandchamp, B., Picat, C., Mignotte, V., Wilson, J. H. P., Te Velde, K., Sankuyl, L., Romeo, P. H., Goossens, M. \& Nordmann, Y. (1989) Tissue specific splicing mutation in acute intermittent porphyria. Proc. Natl. Acad. Sci. USA 86, 661-664.

13. Scobie, G. A., Urquhart, A. J., Elder, G. H., Kalsheker, N. A., Llewellyn, D. H., Smyth, J. \& Harrisons, P. R. (1990) Acute intermittent porphyria caused by a $\mathrm{C} \rightarrow \mathrm{T}$ mutation that produces a stop codon in the porphobilinogen deaminase gene. Hum. Genet. 85, 631-634.

14. Delfau, M. H., Picat, C., De Rooij, F. W. M., Hamer, K., Bogard, M., Wilson, J. H. P., Deybach, J. C.; Nordmann, Y. \& Grandchamp, B. (1991) Two different point mutations G to A in exon 10 of the porphobilinogen deaminase gene are responsible for acute intermittent porphyria. J. Clin. Invest. 86, $1511-1516$.

15. Lee, J-S. \& Anvret, M. (1991) Identification of the most common mutation within the porphobilinogen deaminase gene in Swedish patients with acute intermittent porphyria. Proc. Natl. Acad. Sci. USA 88, 10912-10915.

16. Llewellyn, D. H., Elder, G. H., Kalsheker, N. A., Marsh, O. W. M., Harrison, P. R., Grandchamp, B., Picat, C., Nordmann, Y., Romeo, P. H. \& Grandchamp, B. (1987) DNA polymorphism of human porphobilinogen deaminase gene in acute intermittent porphyria. Lancet $I I, 706-708$.

17. Lee, J-S., Anvret, M., Lindsten, J., Lannfelt, L.; Gellerfor's, P., Wetterberg, L.; Floderus, Y. \& Thunell, S: (1988) DNA polymorphisms within the porphobilinogen deaminase gene in two Swedish families with acute intermittent porphyria. Hum. Genet. 79, 379-381.

18. Wright, D. J. \& Lim, C. K. (1983) Simultaneous determination of hydroxymethylbilane synthase and uroporphyrinogen III synthase in erythrocytes by high performance liquid chromatography. Biochem. J. 213, 85-88.

19. Magnussen, C. R., Levine, J. B., Doherty, J. M., Cheesman, J. O. \& Tschudy, D. P. (1974) A red cell enzyme method for the diagnosis of acute intermittent porphyria. Blood 44, 857-868.

20. Lannfelt, L., Wetterberg, L., Lilius, L., Thunell, S. \& Gellerfors, P. (1989) ELISA for measuring porphobilinogen deaminase in human erythrocytes. Clin. Chim. Acta 83, 227-238. 
21. Lim, C. K. \& Peters, T. J. (1984) Urine and faecal porphyrin profiles by reversed-phase high performance chromatography. in the porphyria. Clin. Chim. Acta 139, 55-63.

22. Mauzerall, D. \& Granick, S. (1956) The occurrence and determination of $\delta$-aminolaevulinic acid and porphobilinogen in urine. J. Biol. Chem. 219, 435-446.

23. Johansson, L., Thunell, S. \& Wetterberg, L. (1984) A filter paper dry blood spot procedure for acute intermittent porphyria population screening by use of whole blood uroporphyrinogen1-synthase assay. Clin. Chim. Acta 137, 317-331.

24. Lannfelt, L. (1990) Immunological determination of porphobilinogen deaminase as a diagnostic measure in acute intermittent porphyria. J. Clin. Chem. Clin. Biochem. 28, 273-278.

25. Moore, M. R. \& Disler, P. B. (1988) Drug-sensitive diseases: Acute porphyrias. Adverse Drug Reaction Bulletin 129, 484-487.

26. Hindmarsh, J. T. (1986) The porphyrias: Recent advances. Clin. Chem. 32, 1255-1263.
27. Lip, G. Y. H., McColl, K. E. L., Goldberg, A. \& Moore, M. R. (1991) Smoking and recurrent attacks of acute intermittent porphyria. Br. Med. J. 32, 507.

28. McColl, K. E. L., Moore, M. R., Thompson, G. G. \& Goldberg, A. (1982) Screening for latent acute intermittent porphyria: The value of measuring both leucocyte $\delta$-aminolaevulinic acid synthase and erythrocyte uroporphyrinogen-1-synthase activities. J. Med. Genet. 19, 271-276.

29. Mustajoki, P. \& Tenhunen, R. (1985) Variant of acute intermittent porphyria with normal erythrocyte uroporphyrinogen-1synthase activity. Eur. J. Clin. Invest. 15, 281-284.

\section{W. S. Wassif, M.D.}

Department of Clinical Biochemistry

King's College School of Medicine and Dentistry

Bessemer Road

London SE5 9PJ

UK 
